\title{
Addressing Elementary Teachers' Alternative Conceptions in Force and Motion with an Interactive Computer Simulation
}

\author{
Lowell M. Gabunilas* \\ Department of Science Education, College of Science and Technology Education, University of Science and \\ Technology of Southern Philippines, Cagayan de Oro City, Philippines \\ *Corresponding author: lowell.gabunilas@ustp.edu.ph
}

\begin{abstract}
This study explores the use of a PhET simulation in addressing the alternative conceptions or misconceptions of elementary teachers on the basic concepts of force and motion. Pretest results show that all the misconceptions listed in the Force Concept Inventory Taxonomy of Misconceptions were found among the respondents, who are elementary science teachers, with $46 \%$ of them believing that gravity get stronger as the object falls. A PhET simulation was employed as intervention and the posttest followed right after. Analyses of their pretest and posttest scores show that the respondents scored higher in the posttest and that there is a significant difference in the pretest and posttest mean scores. However, examination on the pretest and posttest responses per item reveals the positive shift in the responses did not occur in all items, including those items the prevalent misconception falls under which indicates that the intervention did not effectively address some misconceptions.
\end{abstract}

Keywords: PhET, physics, education, misconception, teacher

Cite This Article: Lowell M. Gabunilas, "Addressing Elementary Teachers' Alternative Conceptions in Force and Motion with an Interactive Computer Simulation." International Journal of Physics, vol. 5, no. 5 (2017): 147-153. doi: 10.12691/ijp-5-5-1.

\section{Introduction}

Fundamental concepts in physics are taught in as early as elementary level [13]. Most teachers in the elementary level do not have science backgrounds [9] but are expected to teach physics lessons. With little training in the subject, the task could be challenging to the teachers. Teaching physics in the elementary level is a careful process and those misconceptions that were formed or transferred in the level may survive up to the higher years until they are addressed properly [20].

In the Philippines, where this study was conducted, for example, the scope of the science lessons taught by elementary teachers includes health and biology, earth and space sciences, and physical sciences. The fourth quarter in the Grades 3 to 6 science classes is allocated to physics specifically in the areas of force, motion, and energy [13]. Physics, being one of the most fundamental of all sciences [24], must be carefully taught so as to avoid the occurrence of misconceptions. It is a normal case that the young learners develop misconceptions on their own because they enter the classroom already with their own understanding of the world around them [15]. These misconceptions may be corrected in their learning experiences. Teachers, like their learners, especially those with little science training, may exhibit misconceptions too [5]. Therefore, it is necessary that the teacher must also be well equipped in the subject matter and their held misconceptions be addressed.

Fortunately, in this age of computers, recent developments in ICT have proven to be of big advantage to the academe especially among the science educators [18]. To help augment the learning experiences in the science classroom, scientists, teachers and application developers work together to produce what we now call as simulations or sims. Sims are computer applications especially designed to provide a visual replica or a virtual model of natural phenomena like projectile motion and the flow of electrons [1]. These were also used to address student misconceptions in specific areas of science [16].

Computer-based simulations are considered great tools for science education as they offer real time results and provide wider venue for interaction [12]. In relation to the above statements, this study explores the use of computer based simulations to promote positive change in the conceptions in physics among elementary teachers specifically in the topics of force and motion.

\section{Related Literature}

Misconceptions are hindrances to learning science even the basic scientific principles [17]. Misconceptions in the fundamental concepts may cause difficulty in the learner to grasp more advance concepts [11]. They can survive up to the higher years until addressed properly [20]. Because 
science plays a major role in the modern world, every person must have at least a clear understanding of the basic scientific principles [19]. Misconceptions are not an unusual occurrence. They arise because people at the early stages of their lives develop their own understanding of world around them before entering formal education [10].

Physics is one of the most fundamental of all sciences [24] and teachers facilitating physics lessons must have good grasp of the concepts they are teaching. Teachers, like their students may exhibit misconceptions too [5] and there are evidences that teachers are one of the major sources of student misconceptions [14]. Force and motion are central concepts in classical mechanics which is the foundation of modern physics [7]. This is why force and motion are well placed in the earlier parts in most basic education science curricula. Hence, diagnosis and correction of alternate conceptions must be conducted in the early years of the learner [15]. Furthermore, elementary teachers are expected to teach the basic concepts of force and motion to learners as young as Grade 3 pupils [13] but most of them have no substantial scientific background [9]. In the study of Burgoon, et. al, [5] they found that elementary teachers express misconceptions in different areas of physical sciences in which physics is a major component. In an investigation conducted by Bayraktar [4] among pre-service physics teachers yielded results indicating that they hold strong alternate conceptions about force and motion which are central concepts in Newtonian mechanics. Note that these were pre-service physics teachers, especially trained to teach physics, very much unlike their counterparts in elementary education.

With respect to the above, computer-based simulations, or sims, are seen as one of the good answers to misconceptions [23]. Positive responses are observed from respondents for activities that involve sims [8]. Also, lessons delivered utilizing sims are shown to give more quality knowledge and skills than the traditional approach [2]. This study utilized Phet simulations, among other sims, because they are free, easy to use, and specially designed for science education. According to the Phet website, Phet sims are interactive, research-based simulations covering a wide array of topics in science and mathematics. They replicate physical phenomena and visualize even the invisible. Finally, they give real time responses to any action given to them by the user.

\section{Objectives of the Study}

The study intended to:

1. Identify the misconceptions of the respondents in force and motion.

2. Determine the prevalent misconception among the respondents.

3. Utilize a PhET simulation to address the misconceptions of the respondents

4. Determine the difference between the pretest and posttest mean scores of the respondents.

5. Determine the change in the proportion of misconceptions prior to and following the PhET-based activity.

\section{Methodology}

The study employed a single-group pretest and posttest design. There are three stages in the study. First, the pretest was given to identify the respondents' misconceptions in force and motion. In the second stage, a PhET activity, utilizing a PhET simulation and a worksheet, was used as the intervention. Finally, the posttest was given right after the activity. Informal interviews of the respondents on their views of the use of the PhET sims for instruction were also conducted.

\subsection{Respondents}

The respondents of the study were 38 elementary science teachers from the different public elementary schools. All of them have been teaching physical sciences in the elementary level for more than a year. None of the respondents had ever tried or used a PhET simulation in their classes.

\subsection{Instruments}

The study adopted the 30-item questionnaire, Force Concept Inventory, developed by David Hestenes, Malcolm Wells, and Gregg Swackhammer to assess the respondents' understanding of the most basic concepts in force and motion [11].

\subsection{The PhET Activity}

To serve as a learning guide for the respondents and to facilitate the use of the PhET sims, a worksheet was specially designed for the activity. The following steps were considered and made:

\subsubsection{Formulating the Learning Objectives}

Two learning objectives focusing on force and motion were formulated which are:

1. Investigate how force affects motion.

2. Determine the amount and direction of force required to set an object in motion or make it stop, and speed up or slow down a moving object

The guide questions are mostly basic and focused on the fundamental concepts in force and motion. The activity was made to be conceptual as much as possible by avoiding the use of intermediate to advance mathematical calculations and directing the focus to the fundamental concepts. This was observed because the purpose of the $\mathrm{PhET}$ activity was to promote positive change in the conceptions of the respondents.

\subsubsection{Selecting the PhET Simulation}

The PhET sim "Forces and Motion:Basics" was chosen because it covers the basic concepts in forces in motion, the illustrations and visualizations are simplified, and the measurements do not require advance instrumentation skills.

\subsection{Nature of the PhET Sims}

The PhET sims are highly interactive computer-based applications for teaching mathematics and sciences [1]. 
The name PhET was originally an acronym for "Physics Education Technology". However, PhET has now included many areas of science, aside from physics, and mathematics. PhET provides learners and teachers with interactive sims that can be utilized as virtual laboratories, to visualize the invisible, and to demonstrate concepts. $\mathrm{PhET}$ also provides sims that are game-based for learningwhile-having-fun activities.

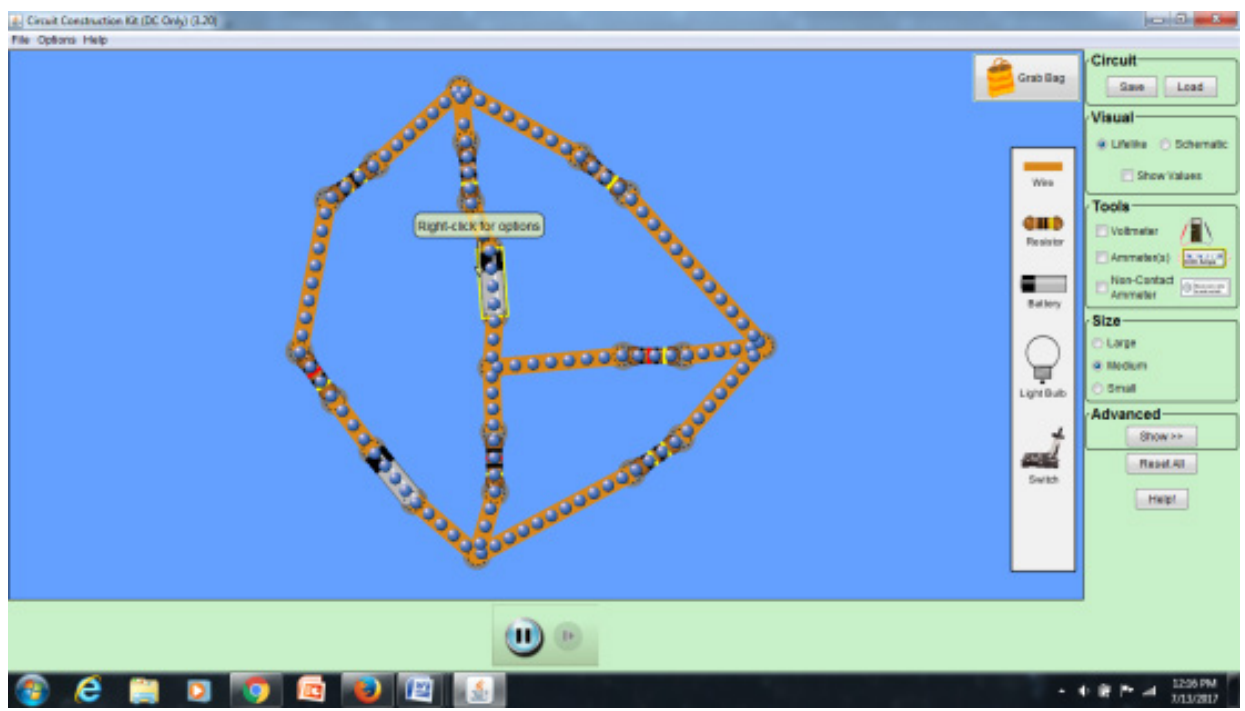

Figure 1. Virtual laboratory

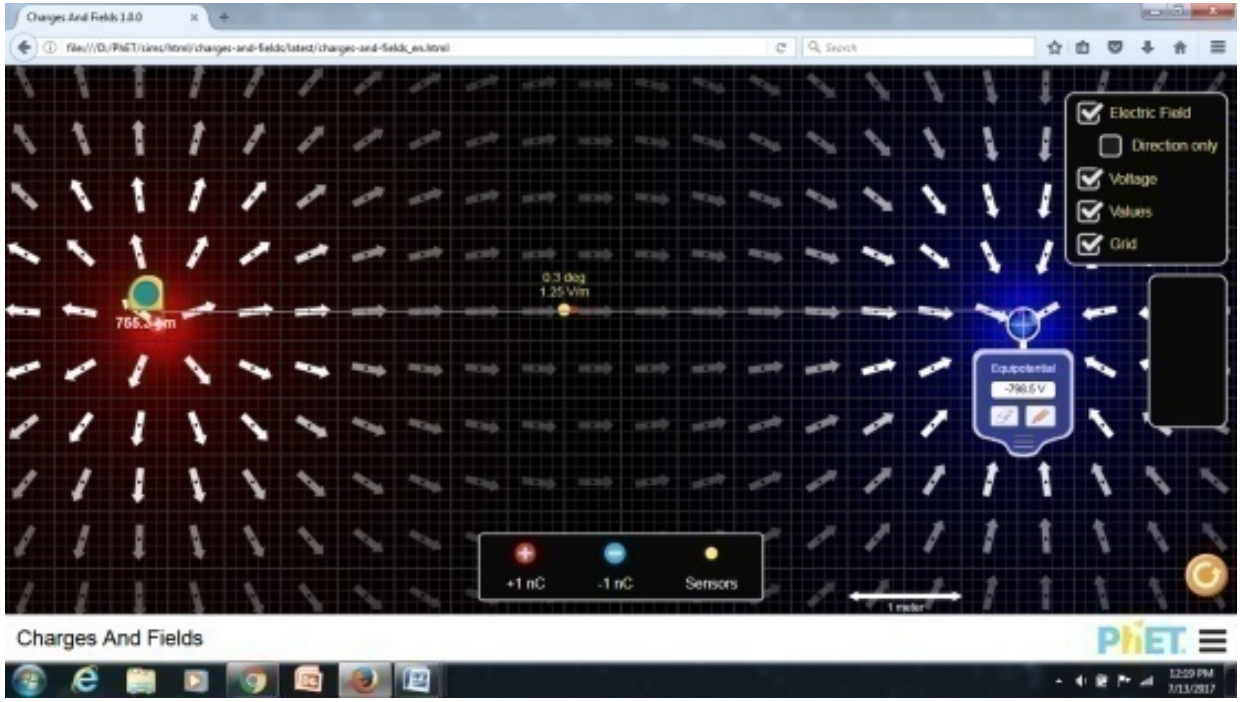

Figure 2. Visualizing the invisible

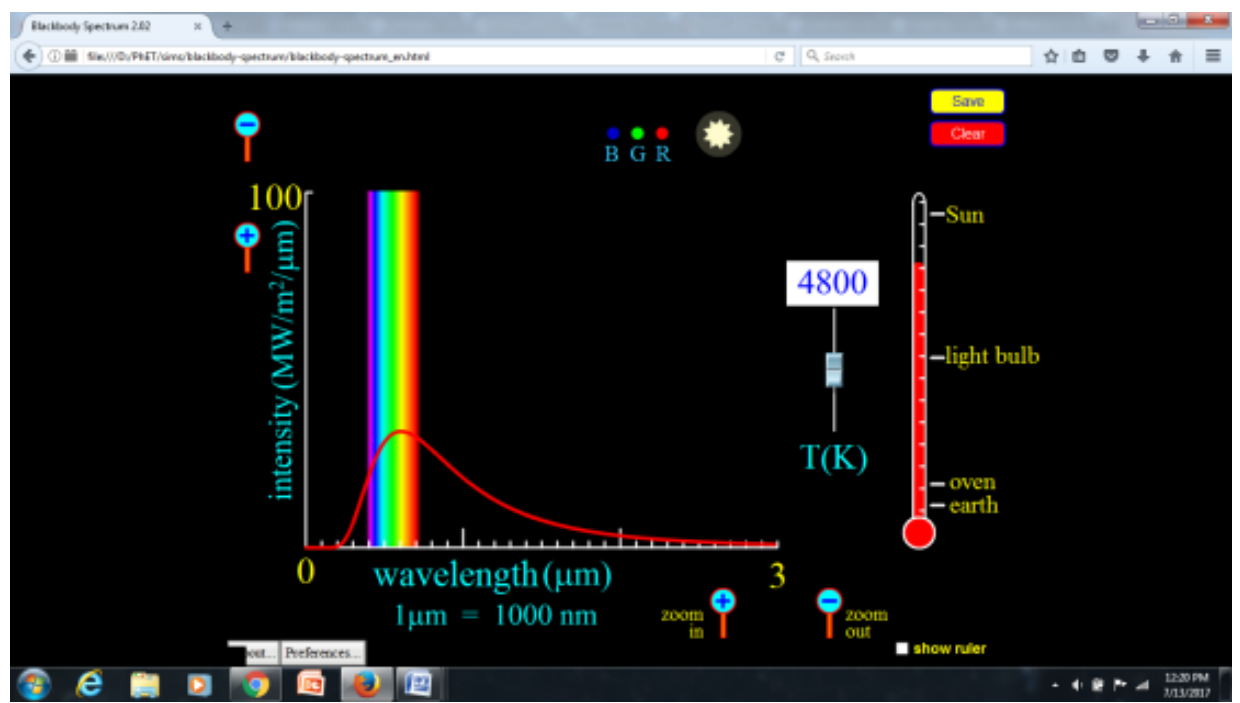

Figure 3. Demonstrating the concept 


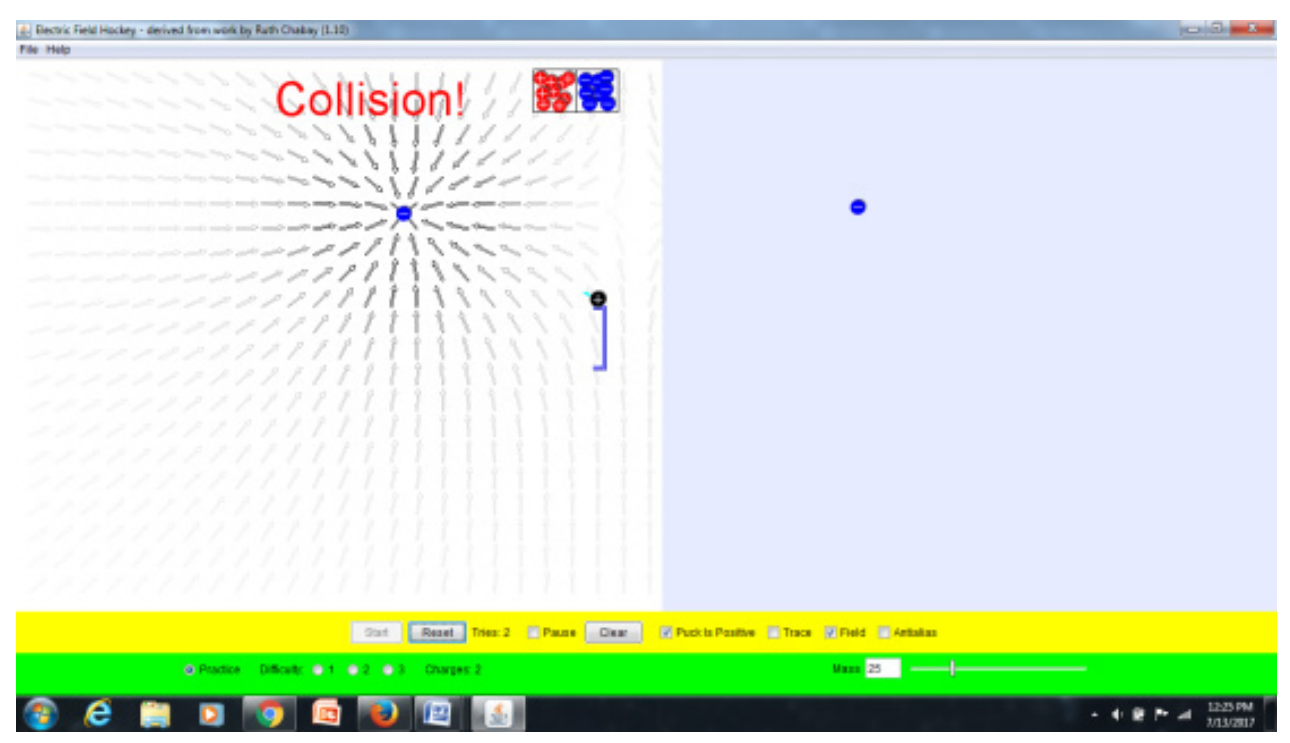

Figure 4. Game-based activity

\subsection{Procedure}

The respondents were asked to answer the 30-item questionnaire called the Force Concept Inventory to identify their misconceptions of the basic concepts of force and motion which also served as their pretest. Afterwards they were introduced to the PhET simulations through a one-hour small lecture. The respondents also reviewed some key concepts and terms in kinematics and dynamics during the small lecture and no item in the Force Concept Inventory was discussed. Following the lecture, they were asked to perform the PhET activity together using the worksheet as their guide. The activity was held inside a computer room where each participant has access to a computer connected to the internet (to access the PhET sim). Although it was an individual activity, discussions among the respondents during the course of the activity was not discouraged. The said activity was expected to last for two hours but some respondents were able to accomplish the task in less than the allotted time. Following the activity, the posttest was given. An informal interview with the respondents was also conducted to gather their views regarding the use of PhET sims for instruction in the elementary level.

\section{Results and Discussions}

The misconceptions or alternative conceptions were identified using the Taxonomy of Misconceptions that comes with the Force Concept Inventory [3,11] as reference. All the misconceptions listed in the taxonomy were found among the respondents. Table 1 shows the majority of wrong responses, which are considered as misconceptions, for every item. In Item 1 for example, in which the correct answer is $\mathrm{C}$ (both metal balls must fall at the same time), $37 \%$ of the respondents chose A (the heavier ball falls faster) as their best answer. This choice is coded as G3 (heavier objects fall faster) in the taxonomy of misconceptions. Only 5\% chose $\mathrm{C}$ as their best answer.
Table 1. Majority misconceptions in each item of FCI (pretest)

\begin{tabular}{|c|c|c|c|c|c|c|c|}
\hline ITEMS & A & B & $\mathrm{C}$ & $\mathrm{D}$ & $\mathrm{E}$ & $\begin{array}{c}\text { No } \\
\text { Answer }\end{array}$ & Majority Misconception / Item \\
\hline 1 & 14 & 6 & 2 & 8 & 8 & 0 & heavier objects fall faster \\
\hline 2 & 6 & 9 & 4 & 8 & 10 & 1 & Impetus dissipation \\
\hline 3 & 4 & 12 & 7 & 4 & 9 & 2 & $\begin{array}{l}\text { Acceleration implies increasing } \\
\text { force }\end{array}$ \\
\hline 4 & 20 & 5 & 4 & 3 & 3 & 3 & Greater mass implies greater force \\
\hline 5 & 12 & 2 & 20 & 3 & 0 & 1 & Impetus supplied by "hit" \\
\hline 6 & 14 & 15 & 7 & 1 & 1 & 0 & Circular impetus \\
\hline 7 & 11 & 10 & 2 & 4 & 10 & 1 & Circular impetus \\
\hline 8 & 15 & 9 & 4 & 8 & 0 & 2 & Last force to act determines motion \\
\hline 9 & 2 & 11 & 1 & 8 & 13 & 3 & Last force to act determines motion \\
\hline 10 & 6 & 7 & 3 & 16 & 6 & 0 & Gradual/delayed impetus build- up \\
\hline 11 & 4 & 15 & 14 & 2 & 2 & 1 & Impetus supplied by "hit" \\
\hline 12 & 1 & 13 & 5 & 2 & 17 & 0 & $\begin{array}{l}\text { Gravity acts after impetus wears } \\
\text { down }\end{array}$ \\
\hline 13 & 1 & 23 & 7 & 3 & 4 & 0 & $\begin{array}{l}\text { Gravity acts after impetus wears } \\
\text { down }\end{array}$ \\
\hline 14 & 22 & 9 & 3 & 2 & 2 & 0 & Ego - centered reference frame \\
\hline 15 & 4 & 8 & 15 & 11 & 0 & 0 & $\begin{array}{l}\text { Most active agent produces greatest } \\
\text { force }\end{array}$ \\
\hline 16 & 2 & 11 & 15 & 6 & 4 & 0 & $\begin{array}{l}\text { Most active agent produces greatest } \\
\text { force }\end{array}$ \\
\hline 17 & 19 & 10 & 1 & 6 & 2 & 0 & Largest force determines motion \\
\hline 18 & 3 & 6 & 10 & 9 & 9 & 1 & Circular impetus \\
\hline 19 & 15 & 6 & 1 & 8 & 7 & 1 & $\begin{array}{l}\text { Velocity - acceleration } \\
\text { undiscriminated }\end{array}$ \\
\hline 20 & 12 & 5 & 17 & 0 & 3 & 1 & $\begin{array}{l}\text { Velocity - acceleration } \\
\text { undiscriminated }\end{array}$ \\
\hline 21 & 8 & 20 & 6 & 1 & 2 & 1 & Last force to act determines motion \\
\hline 22 & 4 & 19 & 4 & 7 & 3 & 1 & $\begin{array}{l}\text { Force causes acceleration to terminal } \\
\text { velocity }\end{array}$ \\
\hline 23 & 5 & 3 & 17 & 11 & 0 & 2 & Last force to act determines motion \\
\hline 24 & 5 & 7 & 13 & 5 & 5 & 3 & Impetus dissipation \\
\hline 25 & 3 & 15 & 7 & 4 & 6 & 3 & $\begin{array}{l}\text { Motion when force overcomes } \\
\text { resistance }\end{array}$ \\
\hline 26 & 8 & 11 & 7 & 4 & 5 & 3 & $\begin{array}{l}\text { Motion when force overcomes } \\
\text { resistance }\end{array}$ \\
\hline 27 & 20 & 9 & 5 & 0 & 1 & 3 & Motion implies active force \\
\hline 28 & 3 & 15 & 8 & 9 & 1 & 2 & Only active agents exert forces \\
\hline 29 & 12 & 10 & 2 & 4 & 7 & 3 & Obstacles exert no force \\
\hline 30 & 1 & 6 & 3 & 13 & 11 & 4 & Impetus supplied by "hit" \\
\hline
\end{tabular}

Cells in Yellow indicate the dominant misconception. 


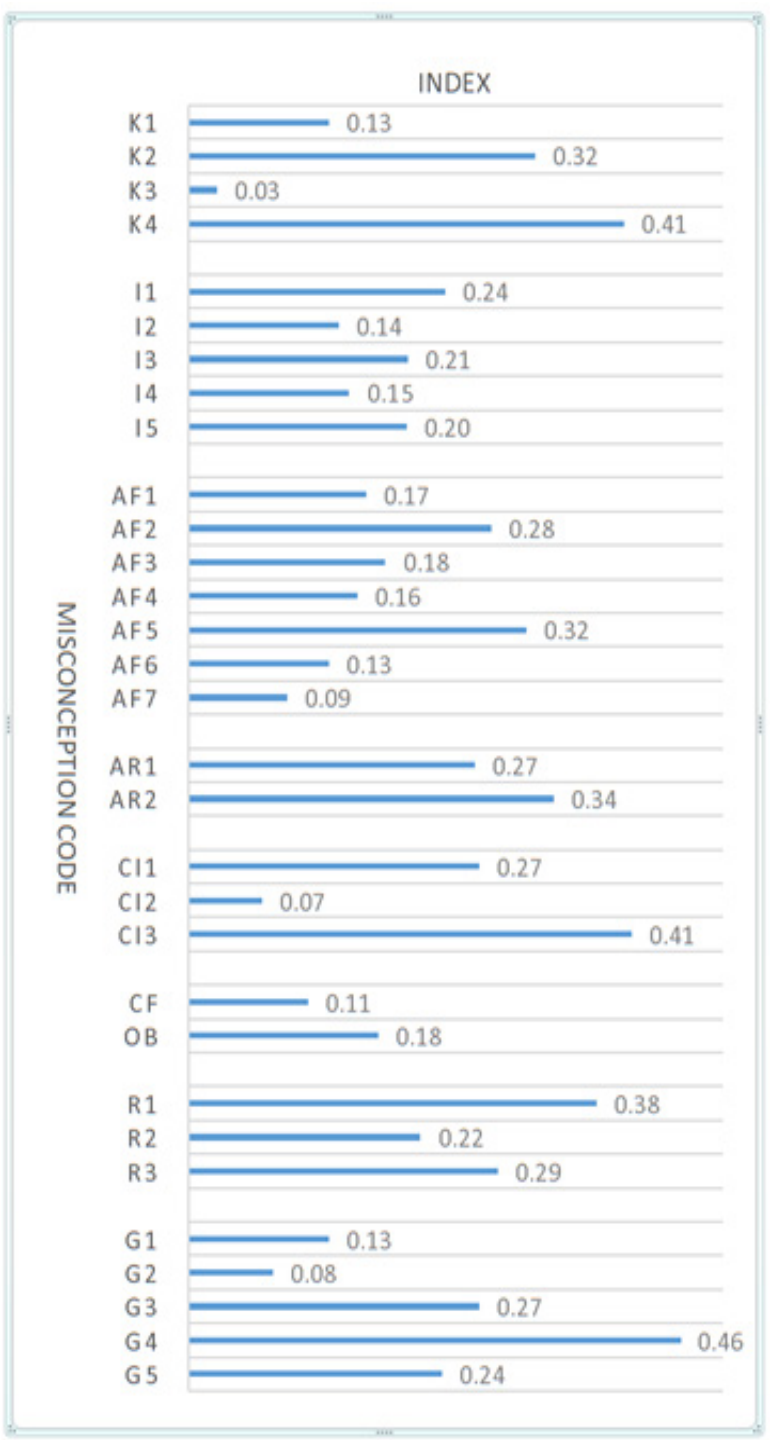

Figure 5. Average misconceptions index based on pretest

To determine the prevalent misconception among the respondents, the average misconception index of every alternative conception was calculated by scoring a misconception every time it occurs in the participant's

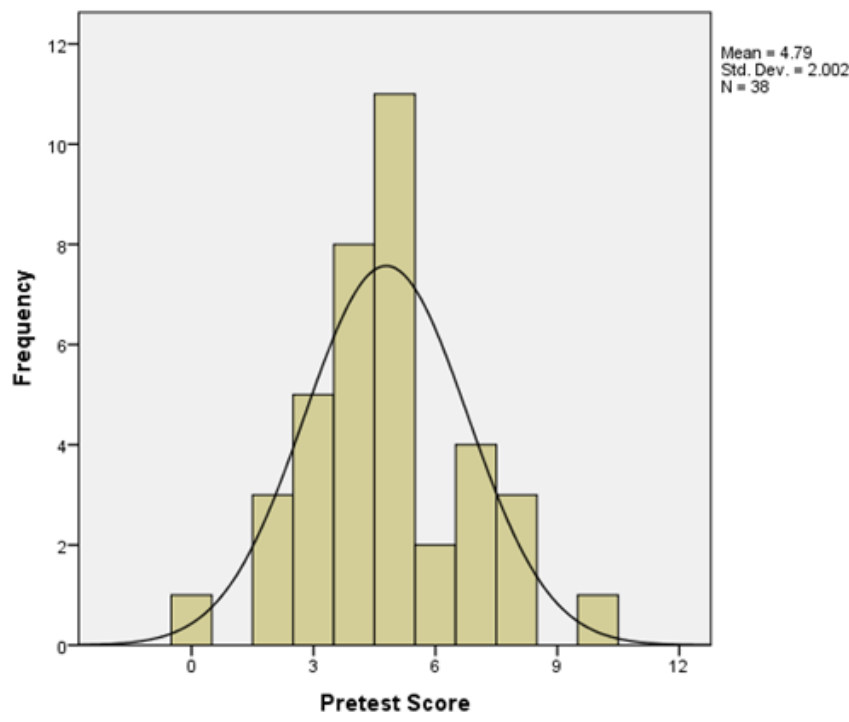

response, summing up the scores, and dividing the sum by the number of items representing the misconception [21] [22]. Using the pretest responses, the misconceptions index was calculated.

As shown by Figure 5, the prevalent misconception, having an index of 0.46 , is G4. This implies that $46 \%$ of the respondents in this study believe that gravity gets stronger as objects fall; an obvious misconception listed in the taxonomy under Gravity as misconception code G4 and falls under FCI items 3 and 13.

After the PhET-based activity, the posttest was given using the same Force Concept Inventory. The scores of respondents in the posttest were compared with their pretest scores.

Figure 6 shows that the respondents scored higher in the posttest $(\mathrm{M}=10.24, \mathrm{SD}=2.498)$ than in the pretest $(M=4.79, S D=2.002)$. Since the scores were from the same group of respondents, and in the absence of a control group, a $\mathrm{T}$ test was conducted to see for significant difference between the mean scores of the pretest (before the PhET- activity) and the posttest (after the PhEt activity).

$\mathrm{T}$ test results show that there is a significant difference in the scores for pretest $(\mathrm{M}=4.79, \mathrm{SD}=2.002)$ and posttest $(\mathrm{M}=10.24, \mathrm{SD}=2.498) ; \mathrm{t}(37)=-11.688, \mathrm{p}=0.00$. These results indicate that the activity using the PhET simulation does have an effect on the scores of the respondents. Furthermore, the results suggest that the use of PhET simulations may help in addressing the misconceptions.

However, exploring deeper into the pretest and posttests results may offer a vantage point of the influence of the $\mathrm{PhET}$ simulation to the conceptions of the respondents. Running the McNemar test, for every item, checks the change in proportion of the pretest and posttest responses. The table below shows the p-value of the McNemar test per item.

Table 2. Paired samples statistics

\begin{tabular}{lccccc}
\hline & & Mean & N & Std. Deviation & Std. Error Mean \\
\hline \multirow{2}{*}{ Pair 1 } & Pretest & 4.79 & 38 & 2.002 & .325 \\
& Posttest & 10.24 & 38 & 2.498 & .405 \\
\hline
\end{tabular}

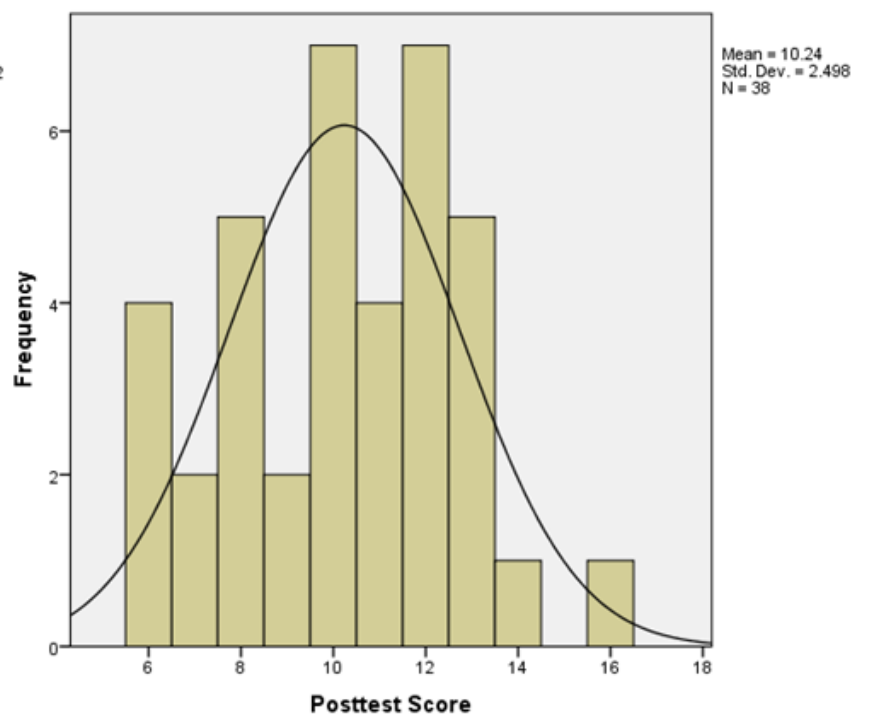

Figure 6. Comparison of pretest and posttest scores 
Table 3. Paired samples test (Pretest-Posttest)

\begin{tabular}{|c|c|c|c|c|c|c|c|c|c|}
\hline & & \multicolumn{5}{|c|}{ Paired Differences } & \multirow{3}{*}{$\mathrm{t}$} & \multirow{3}{*}{$\mathrm{df}$} & \multirow{3}{*}{$\begin{array}{c}\text { Sig. } \\
\text { (2-tailed) }\end{array}$} \\
\hline & & \multirow{2}{*}{ Mean } & \multirow{2}{*}{ Std. Deviation } & \multirow{2}{*}{ Std. Error Mean } & \multicolumn{2}{|c|}{$95 \%$ Confidence Interval of the Difference } & & & \\
\hline & & & & & Lower & Upper & & & \\
\hline Pair 1 & Pretest - Posttest & -5.447 & 2.873 & .466 & -6.392 & -4.503 & -11.688 & 37 & .000 \\
\hline
\end{tabular}

Table 4. McNemar test p-value per item $(\mathrm{N}=38)$

\begin{tabular}{|c|c|c|c|c|c|}
\hline Item & $\begin{array}{c}\text { Total Wrong to Wrong } \\
\text { Responses }\end{array}$ & $\begin{array}{c}\text { Total Right to Wrong } \\
\text { Responses }\end{array}$ & $\begin{array}{c}\text { Total Wrong to Right } \\
\text { Responses }\end{array}$ & $\begin{array}{c}\text { Total Right to Right } \\
\text { Responses }\end{array}$ & p-value \\
\hline 1 & 3 & 0 & 33 & 2 & .000 \\
\hline 2 & 7 & 1 & 25 & 5 & .000 \\
\hline 3 & 26 & 3 & 5 & 4 & .727 \\
\hline 4 & 4 & 0 & 31 & 3 & .000 \\
\hline 5 & 32 & 1 & 4 & 1 & .375 \\
\hline 6 & 6 & 7 & 17 & 8 & .064 \\
\hline 7 & 21 & 8 & 7 & 2 & 1.000 \\
\hline 8 & 24 & 7 & 5 & 2 & .774 \\
\hline 9 & 22 & 11 & 4 & 1 & .118 \\
\hline 10 & 21 & 1 & 12 & 4 & .003 \\
\hline 11 & 32 & 1 & 4 & 1 & .375 \\
\hline 12 & 19 & 11 & 6 & 2 & .332 \\
\hline 13 & 33 & 2 & 2 & 1 & 1.000 \\
\hline 14 & 34 & 2 & 2 & 0 & 1.000 \\
\hline 15 & 7 & 0 & 27 & 4 & .000 \\
\hline 16 & 8 & 1 & 27 & 2 & .000 \\
\hline 17 & 12 & 5 & 16 & 5 & .027 \\
\hline 18 & 28 & 4 & 4 & 2 & 1.000 \\
\hline 19 & 25 & 6 & 6 & 1 & 1.000 \\
\hline 20 & 34 & 0 & 4 & 0 & $\mathrm{n} / \mathrm{a}$ \\
\hline 21 & 34 & 2 & 2 & 0 & 1.000 \\
\hline 22 & 15 & 14 & 4 & 5 & .031 \\
\hline 23 & 30 & 3 & 5 & 0 & .727 \\
\hline 24 & 19 & 3 & 14 & 2 & .013 \\
\hline 25 & 20 & 5 & 11 & 2 & .210 \\
\hline 26 & 29 & 5 & 4 & 0 & 1.000 \\
\hline 27 & 31 & 4 & 2 & 1 & .687 \\
\hline 28 & 11 & 0 & 26 & 1 & .000 \\
\hline 29 & 17 & 5 & 11 & 5 & .210 \\
\hline 30 & 31 & 3 & 4 & 0 & 1.000 \\
\hline
\end{tabular}

The test reveals that the significant change in the proportion of misconceptions prior to and following the PhET activity occurred only at items 1, 2, 4, 10, 15, 16, 17, 22,24 , and 28 . The results indicate that there was positive shift in the understanding of the respondents on concepts falling under these items. No significant change in proportion was observed in items $3,5,6,7,8,9,11,12$, $13,14,18,19,20,21,23,25,26,27,29,30$ which indicate that there was no positive effect on the respondents' misconceptions under these items. The items dealing with non-rectilinear motion or motions in one dimension $(5,6,7,8,9,10,11,12,14,18,21,22$, and 23) with the exception of item 10 also had no significant positive shift in the responses. Table 5 shows the item placement of the topics in the FCI [11,21].

Table 5. Force Concept Inventory Table of Specifications

\begin{tabular}{|c|l|l|}
\hline Label & \multicolumn{1}{|c|}{ Topic } & \multicolumn{1}{c|}{ Item No. } \\
\hline KI & Kinematics & 19,20 \\
\hline FB & Falling Bodies & $\mathbf{1 , 2}, 3,12,14$ \\
\hline L1 & $1^{\text {st }}$ Law of Motion & $6,7, \mathbf{1 0}, 23,24,27$ \\
\hline L2 & $2^{\text {nd }}$ Law of Motion & $8,9, \mathbf{1 7}, 21, \mathbf{2 2}, 26$ \\
\hline L3 & $3^{\text {rd }}$ Law of Motion & $4, \mathbf{1 5}, \mathbf{1 6}, 25, \mathbf{2 8}$ \\
\hline FI & Indentifying Forces & $5,11,13,18,29,30$ \\
\hline
\end{tabular}


In the informal interview, the respondents were asked about their thoughts and opinions on the use of the PhET $\operatorname{sim}$. The respondents mostly agreed that the sim is easy and fun to use and was helpful in making them understand the basic concepts of force and how it affects motion, particularly rectilinear motion. This is evident in the results of the McNemar test that show no significant change in the proportion of misconceptions in the items dealing with non-rectilinear motion. The respondents express eagerness in using the sim in their classes.

\section{Conclusion}

Test results suggest that the PhET simulation may help in addressing misconceptions of the fundamental concepts of force and motion. The use of PhET simulations in science instructions, lectures, and workshops is recommended. Nevertheless, there are misconceptions that exhibit persistence despite the intervention using the PhET simulation. This merits further examination in the future. Lastly, elementary teachers must be given sustainable enrichment activities to address any inadequacy in their conceptual understanding of the foundational science concepts.

\section{Acknowledgements}

The researcher would like to express gratitude to the faculty of the Department of Science and Education of the College of Science and Technology Education, University of Science and Technology of Southern Philippines, chaired by Dr. Maria Theresa M. Fajardo for the opportunity to conduct this study in one of their seminar-workshops for elementary science teachers.

\section{References}

[1] About PhET. (2017). Retrieved August 2, 2017 from https://phet.colorado.edu/en/about

[2] Ajredini, F., Izairi, N., \& Zajkov, O. (2014). Real Experiments versus Phet Simulations for Better High-School Students' Understanding of Electrostatic Charging. European Journal of Physics Education, 5(1), 59.

[3] Bani-Salameh, H., Nuseirat, M., Alkofahi, K.A. (2017). Do First Year College Female and Male Students Hold Different Misconceptions about Force and Motion?. IOSR Journal of Applied Physics. 09. 14-18.

[4] Bayraktar, S. (2009). Misconceptions of Turkish pre-service teachers about force and motion. International Journal of Science and Mathematics Education, 7(2), 273-291.

[5] Burgoon, J., Heddle, M., \& Duran, E. (2010). Re-Examining the Similarities Between Teacher and Student Conceptions About
Physical Science. Journal of Science Teacher Education, 21(7), 859-872.

[6] Champagne, Q. A., Klymkowsky, M.W., Stern, E., Hafen, E., Köhler, K. (2017). Diagnostic of students' misconceptions using the Biological Concepts Instrument (BCI): A method for conducting an educational needs assessment. PLoS ONE 12(5): e0176906.

[7] Chow, T. L. (2013). Classical mechanics. CRC Press.

[8] Clark, T. M., \& Chamberlain, J. M. (2014). Use of a PhET interactive simulation in general chemistry laboratory: Models of the hydrogen atom. Journal of Chemical Education, 91(8), 1198-1202.

[9] Giamellaro, M., Lan, M.-C., Ruiz-Primo, M.A., Li, M. (2011). Addressing Elementary Teacher Misconceptions in Science and Supporting Peer Learning Through Curriculum Mapping. DEISA. 5.

[10] Henriques, L. (2002). Children's ideas about weather: A review of the literature. School Science and Mathematics, 102(5), 202-215.

[11] Hestenes, D., Wells, M., Swackhamer, G. (1992). Force Concept Inventory. The Physics Teacher, Volume 30, p. 141-158.

[12] Jayakanthan, R. (2002). Application of computer games in the field of education. The Electronic Library, Vol. 20 Issue: 2, pp.98-102.

[13] K to 12 Basic Education Curriculum. (2017). Retrieved August 2, 2017 from http://www.deped.gov.ph/k-to-12/bec-cgs/als-program.

[14] Kaltakci-Gurel, D., Eryilmaz, A., \& McDermott, L. C. (2016). Identifying pre-service physics teachers' misconceptions and conceptual difficulties about geometrical optics. European Journal of Physics, 37(4), 045705.

[15] Kambouri, M. (2011) Children's misconceptions and the teaching of early years science: a case study. Journal of Emergent Science, 2 (2). pp. 7-16.

[16] Lee, J., Shin, E. J., \& Kim, J. B. (2015). Conceptual Change via Instruction based on PhET Simulation Visualizing Flow of Electric Charge for Science Gifted Students in Elementary School. Journal of Korean Elementary Science Education, 34(4), 357-371.

[17] National Research Council. (1997). Science Teaching Reconsidered: A Handbook. Washington, DC: The National Academies Press.

[18] Noor-Ul-Amin, S.. (2016, October 30). An Effective use of ICT for Education and Learning by Drawing on Worldwide Knowledge, Research, and Experience: ICT as a Change Agent for Education (A LITERATURE REVIEW). Retrieved from http://www.nyu.edu/classes/keefer/waoe/amins.pdf.

[19] Pompea, S. M., \& Stepp, L. M. (1995, October). Great ideas for teaching optics. In SPIE's 1995 International Symposium on Optical Science, Engineering, and Instrumentation (pp. 168-172). International Society for Optics and Photonics.

[20] Queloz, A. C., Klymkowsky, M. W., Stern, E., Hafen, E., \& Köhler, K. (2017). Diagnostic of students' misconceptions using the Biological Concepts Instrument (BCI): A method for conducting an educational needs assessment. PloS one, 12(5), e0176906.

[21] Roleda, Robert C. (1999). Conceptual Understanding of Forces Among Physics Majors. De La Salle University - Manila.

[22] Tadeo Jr, D. A., \& Roleda, L. S. (2013). TRANSLATION AND VALIDATION OF THE FORCE CONCEPT INVENTORY (FCI) IN FILIPINO.

[23] Wieman, C. E., Adams, W. K., Loeblein, P., \& Perkins, K. K. (2010). Teaching physics using PhET simulations. The Physics Teacher, 48(4), 225-227.

[24] Young, H. D., \& Freedman, R. A. (2012). University physics. Boston, MA: Pearson. 